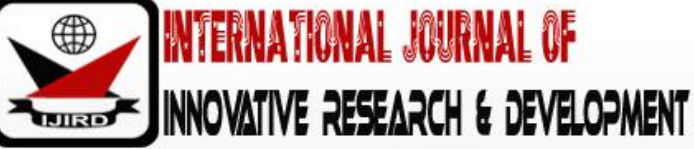

ISSN 2278 - 0211 (Online)

\section{Effect of Macro Economic Factors on Stock Prices in Banking Sector Companies in Indonesia Stock Exchange (BEI): Studies on Bumn and Bumd Banks for the Period of 2013 - 2017}

Said Djamaluddin
Postgraduate Lecturer, Mercubuana University, Jakarta, Indonesia
Zakina Rahmatika Ekawijayanti
Postgraduate Alumni, Mercubuana University, Jakarta, Indonesia
Aty Herawati
Postgraduate Lecturer, Mercubuana University, Jakarta, Indonesia

\begin{abstract}
:
This study aims to examine and analyze the effects of macroeconomic variables, namely: the interest rate of Bank Indonesia, currency exchange rate, and Gross Domestic Products on the stock prices of banking in the Indonesia Stock Exchange. The analysis technique used is multiple regression. The results found that only the interest rate of Bank Indonesia significantly affects the stock prices of banking while the currency exchange rate and the Gross Domestic Product have no effect on the stock prices of banking in the Indonesia Stock Exchange. This study uses only three macroeconomics variables, so that further research needs to find other macroeconomics variables that are supposed to influence the stock prices of banking in the Indonesia Stock Exchange.
\end{abstract}

Keywords: Macroeconomics, interest rate of Bank Indonesia, currency exchange rate, Gross Domestic Product, and bank stock prices

\section{Introduction}

Investment growth in a country will be influenced by the country's economic growth. The better the level of a country's economy, the better the level of prosperity of its population. This higher level of prosperity is generally characterized by an increase in the level of community income. With this increase in income, more and more people will have excess funds, the excess funds can be utilized to be saved in the form of savings or invested in securities that are traded on the capital market.

The capital market has an important role for a country's economy because the capital market performs two functions, namely first as a means for business funding or as a means for companies to get funds from the investor community. Funds obtained from the capital market can be used for business development, expansion, addition of working capital and others. Both capital markets become a means for people to invest in financial instruments.

According to Lusiana Silim (2013), stock prices are influenced by many internal and external factors. Internal factors are factors that are directly related to the performance and condition of the company as seen from the financial statement data. While external factors are factors that are not directly related to the condition of the company but factors outside the company can be seen from macroeconomic conditions such as inflation rates, gross domestic product, the money supply, the BI rate and so forth.

Economic growth with the acquisition of high gross domestic product is a picture of the welfare of production factors that also contribute to creating national welfare from both the real sector and the non-real sector. This means that the greater the Gross Domestic Product, the higher the productivity of production factors and the higher the activity in the domestic stock exchange in creating national independence.

The value of GDP consistently increases every year until the largestGDP is achieved in 2017 in the amount of Rp 9,912,703.60 billion with a stock price of 4,038.57 million. But the increase in GDP is not always in line with the rise in the stock price index. Along with the increase in the number of GDP in Indonesia, in 2015 the share price experienced a decrease of 2,057.45 million due to the weakening of the rupiah exchange rate and a decrease in interest rates that resulted in slowing economic growth.

The rupiah exchange rate is a comparison of the value of the rupiah price with the price of foreign currencies, each country has its own exchange rate, which value is a comparison of the value of a currency with other currencies called foreign exchange rates. Information of the rupiah against the US dollar generally is considered by companies in Indonesia, because the US Dollar is used by the company in general to make the payment of production materials and other business transactions. The exchange rate is also very influential for companies that want to invest, because if the foreign exchange 
market is more attractive than the capital market, investors will generally switch investments to the foreign exchange market, therefore changes in the exchange rate will affect stock prices in the capital market.

In the past 5 years, the trend of the exchange rate of the Rupiah against the US Dollar continues to increase, this can certainly affect the sale and purchase of shares on the Indonesia Stock Exchange. Usually the selling value of a company's shares in Indonesia will decline when there is an increase in the Rupiah exchange rate. When investors decide to sell these shares, they can suffer losses. This can happen because the purchase price of shares is more expensive than the selling price of shares. Interest rates are one of the macroeconomic factors that affect stock prices. As interest rates have increased the price of the stock will decline, and vice versa when the interest rate has decreased then the stock price will increase. High interest rates, will make investors switch to investing in savings or deposits that result in shares of no interest so that the stock will go down.

Economic conditions and the ups and downs of macro variables in a country can affect stock prices, including in the banking sector. The financial services industry is one of the most vital industries in the country. Its role in supporting the economic activities of the community can be seen from the two main functions it has, namely the place to store funds (funding) and channeling funds (lending). When the performance of this industry is disrupted, it is likely that the pace of the economy will slow down. The object that will be used in this study is the banking industry which is listed on the Indonesia Stock Exchange. This sector was chosen as the object of research because the banking sector is considered to play a very important role in increasing national economic growth. This role is manifested in its main function as an intermediary institution between debtors and creditors. Banks serve as a bridge for real sector financing, both in the context of improving the business climate and investment climate and in the context of job creation. The intermediary role of banking institutions is very influential on a country's economic growth. When there is a decrease in the amount of credit extended due to caution from the bank, indirectly there will be a slowdown in economic growth in the country concerned. That way if a country wants to make improvements / economic improvements it is also necessary to look at the indicators of banking companies. Research is carried out for motivated the phenomena on different results of the study were carried out by several studies earlier.Research which conducted Maria Ratna Marisa Ginting, et al (2016) managed to prove that the value of the exchange effect significantly to the price of the stock. But the research which conducted by La Rahmat Hidayat, et al (2017) prove that the value of the exchange does not affect significantly toprice stocks. Research which conducted by Maria Ratna Marisa Ginting, et al (2016) succeeded in proving that the rate of interest affects negatively and significantly to the price of the stock. However, studies are conducted by La Rahmat Hidayat, et al proved that the rate of interest influence positively and significantly to the stock.

The issue of trade war between the United States and China is the cause of the world economic slowdown. This global condition also affected the Indonesian economy, because China is a major partner country for Indonesia's export destinations. This condition will certainly affect investors to invest in the capital market, especially stocks and affect macroeconomic variables such as interest rates, GDP and exchange rates have changed so it makes this research interesting to be examined again and based on the research gap from previous research above researchers hoping to find a different conclusion.

\section{Theoretical Review}

\subsection{Signaling Theory}

Signaling theory is a theory that discusses the ups and downs of prices in the market such as stock prices, bonds and the like. So that it will have an influence on investor decisions.

Investors' responses to positive and negative signals are very influential in market conditions, they will react in various ways in responding to these signals, such as hunting down shares that are sold or taking actions in the form of inaction such as "wait and see " or wait and see first developments Then take action. And to understand the wait and see decision is not something that is not good or wrong, but it is seen as an investor reaction to avoid the emergence of greater risk due to market factors that have not been profitable or sided with it.

\subsection{Investment Theory}

Sunariyah (2003: 4) defines investment as an investment for one or more assets that are owned and usually for a long time in the hope of getting profits in the future. According to Taswan and Soliha (2002: 168), the decision to invest can be made by individuals or business entities (including banking institutions) that have excess funds. Investments can be made both in the money market and in the capital market or placed as credit to people in need.

\subsection{Portfolio Theory}

Portfolio theory is a theory that analyzes how to choose a combination of various forms or types of assets ( assets ) based on the risk of these types of assets (securities / physical assets) (Nopirin, 1997: 111). The purpose of the establishment of a portfolio o stake is how the risks are minimal gain certain advantages, or at risk of certain to obtain maximum investment gains.

\subsection{Stock}

Stock is one type of investment that promises returns for investors. Shares obtained through purchase or other means, which give shareholders the right to dividends and others according to the investment in the company.

Shares can be defined as a sign of capital participation of a person or party (business entity) in a company or limited liability company. By including this capital, the party has a claim on company income, a claim on company assets, and is 
entitled to attend the General Meeting of Shareholders (GMS). Basically there are two benefits to investors by buying or owning shares, including:

\subsubsection{Dividend}

Dividends are the distribution of profits provided by the company and derived from profits generated by the company. Dividends are given after obtaining approval from the shareholders at the GMS. If an investor wants to get a dividend, then the investor must hold the shares for a relatively long period of time, namely until the ownership of the shares is in the period in which they are recognized as shareholders entitled to receive dividends.

\subsubsection{Capital Gain}

Capital Gain is the difference between the purchase price and the selling price. Capital gains are formed by the existence of stock trading activities in the secondary market.

As an investment instrument, stocks have risks including:

\subsubsection{Capital Loss}

Is the opposite of Capital Gain, which is a condition where investors sell shares lower than the purchase price

\subsubsection{Liquidation Risk}

The company whose shares are owned is declared bankrupt by the Court, or the company is dissolved. In this case the claim rights of the shareholders get the last priority after all company obligations can be paid (from the sale of company assets). If there is still left over from the sale of the company's wealth, then the remainder is divided proportionally to all shareholders. However, if there is no remaining company wealth, shareholders will not get the results of the liquidation. This condition is the heaviest risk of shareholders. For this reason, a shareholder is required to continuously follow the company's development.

\subsubsection{There Is No Dividend Distribution}

Companies whose shares are owned by investors at certain times will distribute dividends to shareholders. This was determined at the General Meeting of Shareholders (GMS). If the RUPS is determined not to distribute dividends, then the investor will lose income on the dividends from the ownership of the shares.

\subsubsection{Delisting from the Exchange}

Delisting of companies on the exchange can also occur. If a company is no longer listed on the stock exchange, the company will change its status from a public company to a private company. If that happens, then the investor will have difficulty in buying and selling transactions or entering and leaving stock ownership.

\subsection{Currency Exchange Rates}

Currency exchange rates or often referred to as exchange rates are the prices of one unit of foreign currency in the domestic currency or it can also be said to be the price of the domestic currency against foreign currencies. The exchange rate consists of:

\subsubsection{Nominal Exchange Rate (Nominal Exchange Rate)}

The nominal exchange rate is the price of one unit of foreign currency in the value (size) of the domestic currency.

\subsubsection{Real Exchange Rate (Real Exchange Rate)}

The real exchange rate (real exchange rate) is used for exchanging value (comparing) the relative prices of goods and services in the country with the price of goods and services abroad.

\subsection{Interest Rates}

Interest rates are the value, level, price or profit given to investors from the use of investment funds on the basis of calculating the economic value within a certain time period. Bank interest rates are used to control a country's economy. Interest rates are set and determined by the government which aims to maintain the sustainability of a country's economy. This interest rate is important to be taken into account because the average investor who always expects greater investment returns.

According to Novianto (2011: 22), based on its form the interest rate is divided into two types, namely:

- Nominal interest rate is the interest rate in money value. This interest rate is a value that can be read in general. This interest rate shows a number of rupiah for every one invested.

- Real interest rates are interest rates that have been corrected due to inflation and are defined as nominal interest rates minus the inflation rate.

\subsection{Gross Domestic Product (GDP)}

One important indicator to determine the economic conditions in a country in a given period is the Gross Domestic Product (GDP) data, both at current prices and at constant prices. GDP is basically the amount of added value produced by all business units in a particular country, or is the sum of the value of final goods and services produced by all economic units. GDP at current prices illustrates the value added of goods and services calculated using the prices that 
apply at each year, while GDP at constant prices shows the value added of those goods and services that are calculated using prices that apply at a certain year as a basis. GDP at current prices can be used to see shifts and economic structure, while constant prices are used to determine economic growth from year to year.

\subsection{Bank}

According to Kuncoro in his book Banking Management, Theory and Application (2002: 68), the definition of a bank is a financial institution whose main business is raising funds and channeling these funds back to the public in the form of credit and providing services in the payment traffic and circulation of money. Therefore, in carrying out their daily business activities, tires must have funds in order to provide credit to the community. The funds can be obtained from bank owners (shareholders), the government, Indonesian banks, overseas parties, and the domestic community. Funds from the bank owner in the form of a capital deposit made at the time of the bank's establishment.

According to the Republic of Indonesia State Law No. 10 of 1998 dated 10 November 1998 concerning banking, which is meant by the Bank is a business entity that collects funds from the public in the form of deposits and distributes them to the public in the form of credit or in other forms in order to improve the lives of many people. It can be concluded that the banking business includes three activities, namely raising funds, channeling funds, and providing other bank services.

\subsection{Framework}

With this, a link is made between GDP, Interest Rates and Exchange Rates on Banking Stock Prices with the following framework:

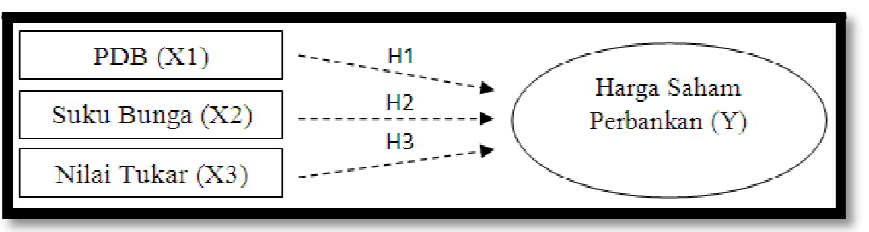

Figure 1: Framework

This study intends to examine the independent variables consisting of GDP, Interest Rates and Exchange Rates on the dependent variable, namely the Banking Stock Price.

\subsection{Hypothesis}

Based on the theory and framework and empirical study, the hypothesis of this research is:

- H1 It is suspected that there is an influence of Gross Domestic Product (GDP) on stock prices partially in the banking subsector on the Indonesia Stock Exchange in 2013-2017

- H2 It is suspected that there is an interest rate effect on stock prices partially on the banking subsector on the Indonesia Stock Exchange in 2013-2017

- H3 It is suspected that there is an effect of the Rupiah Exchange Rate on stock prices partially on the banking subsector on the Indonesia Stock Exchange in 2013-2017

\section{Research Methods}

This type of research used in this study is non-experimental namely descriptive quantitative and analytical research designs. According to Nana Sudjana and Ibrahim (2007: 64) what is meant by descriptive research is research that seeks to describe a phenomenon, event, event that is happening at the present time. This research approach is used to test the hypotheses that have been set. Sugiyono (2008 : 14) explains, quantitative research methods can be interpreted as a research method based on the philosophy of positivism, used to examine specific populations or samples, sampling techniques are generally carried out randomly, data collection using research instruments, data analysis is quantitative / statistics with the aim to test the hypothesis that has been set. The population used in this study is the price of banking sector shares listed on the Indonesia Stock Exchange (IDX). The research period is January 2013 - December 2017 in the form of quarterly data. The data source of this research is to use secondary data in the form of a closing price of banking sector stock prices obtained from the Indonesia Stock Exchange (BEI) gallery. Exchange rates, interest rates and gross domestic product (GDP) is quoted on the official website of Bank Indonesia www.bi.go.id.

Below is a list of the Bank that will be used in this study:

\begin{tabular}{|c|c|}
\hline PT Bank Negara Indonesia (BNI) & BBNI \\
\hline PT Bank Rakyat Indonesia (BRI) & BBRI \\
\hline PT Bank Tabungan Negara (BTN) & BBTN \\
\hline PT Bank Mandiri & BMRI \\
\hline PT BPD West Java and Banten & BJBR \\
\hline PT BPD East Java & BJTM \\
\hline PT BPD Banten & BEKS \\
\hline
\end{tabular}

Table 1: List of Banks 
Data collection techniques in this study using documentation techniques. According to Sugiyono (2009: 422) documentation technique is a data collection technique by examining documents relating to the research conducted. The document is in the form of official data about interest rates, exchange rates, GDP and stock prices.

Methods of analysis were used to test the hypothesis is a model analysis regression linear multiple. Regression Multiple an equation regression by using two or more variables independent. Analysis of regression doubled in the research is used to determine the effect of GDP, Rate Interest and Currency Exchange Rates to Banking Stock Prices.

\section{Results and Discussion}

\subsection{Descriptive Statistical Analysis}

\begin{tabular}{|c|c|c|c|c|}
\hline & BI_Rate & Exchange Rate & GDP & Stock \\
\hline The mean & 0.063250 & 12645.65 & 1700407. & 2381,156 \\
\hline Median & 0.070000 & 13132.00 & 2251692. & 2202,577 \\
\hline Maximum & 0.077500 & 14657.00 & 2552217. & 4038,571 \\
\hline Minimum & 0.042500 & 9719,000 & 671320.3 & 1640,581 \\
\hline Std. Dev & 0.013281 & 1242,911 & 834797.2 & 610.3709 \\
\hline Skewness & -0.383640 & -1.003156 & -0.374175 & 1.117989 \\
\hline Kurtosis & 1.428430 & 3,534208 & 1.188000 & 3.901926 \\
\hline Jarque-Bera & 2.548790 & 3.592220 & 3.202810 & 4,844224 \\
\hline Probability & 0.279600 & 0.165943 & 0.201613 & 0.088734 \\
\hline Sum & 1.265000 & 252913.0 & 34008133 & 47623.12 \\
\hline Sum Sq. Dev & 0.003351 & 29351735 & $1.32 \mathrm{E}+13$ & 7078500. \\
\hline Observations & 20 & 20 & 20 & 20 \\
\hline
\end{tabular}

Table 2: Descriptive Research Variables

Based on the descriptive statistical test table above, it is known that the amount of data or $\mathrm{n}$ used in this study is 20. The banking sector stock price as the dependent variable which is a BUMN and BUMD Bank listed on the Indonesia Stock Exchange (BEI) consists of 7 Banks with a value of middle (median) obtained for 2,202,577, mean (mean) of $2,381,156$ which means the average stock price of the banking sector for five years is approaching the middle value. Furthermore, the standard deviation value is 610.3709 , the minimum value (smallest value) of shares is $1,640,581$ and the maximum value of shares is 4,038,571.

\subsection{Normality Test}

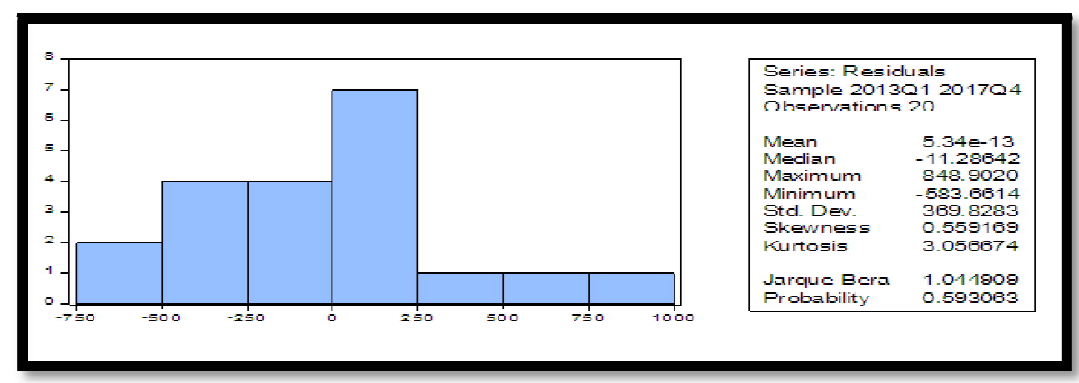

Table 3: Normality Test

Based on Table 3, dapat known that Jarque Bera test scores are at a probability of 1.044909 to $0.593063>$ 0.05 . Thus the research data in this research model can be stated normal.

4.3. Multicollinearity Test

\begin{tabular}{|c|c|c|c|}
\hline \multicolumn{3}{|c|}{ Variance Inflation Factors } & \\
\hline \multicolumn{3}{|c|}{ Date: 10/ 08/ 19 Time: 13:44 } & \\
\hline \multicolumn{3}{|c|}{ Sample: 2013Q1 2017Q4 } & \\
\hline \multicolumn{3}{|c|}{ Included observations: 20 } & \\
\hline & Coefficient & Uncentered & Centered \\
\hline Variable & Variance & VIF & VIF \\
\hline BI RATE & $1.17 \mathrm{E}+08$ & 59,94012 & 2,409648 \\
\hline EXCHANGE RATE & 0.028057 & 557.5480 & 5.070329 \\
\hline GDP & $8.77 \mathrm{E}-08$ & 38.35734 & 7.146393 \\
\hline C & 1997123. & 245.9241 & NA \\
\hline
\end{tabular}

Table 4: Multicollinearity Test 
From Table 4 it can be seen that all independent variables have a VIF value of less than 10 , so it can be concluded that there are no symptoms of multicollinearity in this research model.

\subsection{Heterokedasticity Test}

\begin{tabular}{|c|c|c|c|}
\hline \multicolumn{3}{|c|}{ Heteroskedasticity Test: Glejser } & \\
\hline F-statistics & 0.667361 & Prob. F $(3,16)$ & 0.5843 \\
\hline Obs * R-squared & 2.224278 & Prob. Chi-Square (3) & 0.5272 \\
\hline Scaled explained SS & 1.922808 & Prob. Chi-Square (3) & 0.5886 \\
\hline
\end{tabular}

Table 5: Heterokedasticity Test

The decision whether or not heteroscedasticity occurs in the linear regression model is by looking at the Prob Value. F-statistics ( $\mathrm{F}$ arithmetic). If the value of Prob. F count larger than the alpha level of $0.05(5 \%)$ then $\mathrm{H}_{0}$ accepted meaning not happen heteroskedastisitas, whereas if the value of Prob. F count is smaller than the alpha level of 0.05 (5\%) then $\mathrm{H}_{0}$ is rejected, which means going heteroskedastisitas.

Prob value F count equal to 0.5843 greater than the rank of alpha 0:05 (5\%) so that, by testing the hypothesis, $\mathrm{H}_{0}$ accepted meaning not happen heterokedastisitas.

\subsection{Autocorrelation Test}

\begin{tabular}{|c|c|c|c|}
\hline \multicolumn{3}{|c|}{ Breusch-Godfrey Serial Correlation LM Test: } & \\
\hline F-statistics & 2.326278 & Prob. F(2.14) & 0.1342 \\
\hline Obs*R-squared & 4.8888652 & Prob. Chi-Square (2) & 0.0826 \\
\hline
\end{tabular}

Based on Table 6 it can be seen that the probability of Obs * R-squared is 0.0826 (Prob.> 0.05), so it can be concluded that the equation model does not experience autocorrelation problems.

4.6. Analysis Regression Linear Regression

\begin{tabular}{|c|c|c|c|c|}
\hline \multicolumn{5}{|c|}{ Dependent Variable: STOCK } \\
\hline \multicolumn{5}{|c|}{ Method: Least Squares } \\
\hline \multicolumn{5}{|c|}{ Date: 10/ 08/19 Time: 13:43 } \\
\hline \multicolumn{5}{|c|}{ Sample: 2013Q1 2017Q4 } \\
\hline \multicolumn{5}{|c|}{ Included observations: 20} \\
\hline Variable & Coefficient & Std. Error & t-Statistics & Prob. \\
\hline BI RATE & -34416.25 & 10806.63 & -3.184734 & 0.0058 \\
\hline EXCHANGE RATE & 0.157992 & 0.167501 & 0.943228 & 0.3596 \\
\hline GDP & $-5.96 \mathrm{E}-05$ & 0,000296 & -0.201299 & 0.8430 \\
\hline $\mathrm{C}$ & 2661,418 & 1413,196 & 1.883261 & 0.0780 \\
\hline R-squared & 0.632876 & \multicolumn{2}{|c|}{ Mean dependent var } & 2381,156 \\
\hline Adjusted R-squared & 0.564040 & \multicolumn{2}{|c|}{ SD dependent var } & 610.3709 \\
\hline SE of regression & 403.0110 & \multicolumn{2}{|c|}{ Akaike info criterion } & 15,01266 \\
\hline Sum squared resid & 2598686. & \multicolumn{2}{|c|}{ Schwarz criterion } & 15,1181 \\
\hline Log likelihood & $-146,1266$ & \multicolumn{2}{|c|}{ Hannan-Quinn criter. } & 15.05154 \\
\hline F-statistics & 9.194008 & \multicolumn{2}{|c|}{ Durbin-Watson stat } & 0.943003 \\
\hline Prob (F-statistic) & 0,000904 & & & \\
\hline
\end{tabular}

Table 7: Results of Analysis Regression Linear Regression

By taking into account the regression model and the results of multiple linear regressions, we get the equation of the factors that influence the Stock Price of the Banking Sector consisting of State-Owned Banks and Regional-Owned Banks that are flat on the Indonesia Stock Exchange. as follows:

STOCK = 2661,418 - 34416.25 BI RATE + 0.157992 EXCHANGE - 5.96 GDP

\subsection{Discussion}

Based on various parameters in the regression equation regarding the factors that affect the Stock Price of the Banking Sector, especially BUMNBanks and BUMD Banks, interpretations can be given as follows:

Constants (Coefficients c)

The constant value is 2661,418 which means that if the independent variable consisting of the exchange rate (US $\$$ to Rupiah), interest rate (BI Rate) and Gross Domestic Product (GDP) is equal to zero, then the change in the banking sector stock price index will be 2661,418 . 


\subsubsection{BI Rate Coefficient}

The BI Rate has a negative effect on the stock price index of the banking sector with a regression coefficient of 34416.25 which means that if the BI Rate increases by $1 \%$ then the stock price of the banking sector will decrease by 34416.25 assuming that the exchange rate and GDP variables are in constant condition.

Based on Table 7 , it can be seen that the BI Rate variable with a two-tailed test that uses a significant level of $\alpha=5 \%$, obtained t-Statistic value of -3.184734 and a probability of $0.0058 \varangle 0.05$. Thus, Ho is rejected and Ha is accepted, meaning that it has a partially significant effect between interest rates (BI Rate) on the stock prices of the banking sector. The negative regression coefficient indicates that the greater the BI Rate, the lower the stock price of the banking sector on the IDX.

The results of this study are consistent with research conducted by Rini Astuti, et al (2016) who found that interest rates had a significant negative effect on the Composite Stock Price Index, indicating that the increase in interest rates imposed by Bank Indonesia would have an impact on shareholders.

\subsubsection{Exchange Rate Coefficient}

The exchange rate (US \$ to Rupiah) has a positive influence on the stock price of the banking sector with a regression coefficient of 0.157992 , which means that if the foreign exchange rate increases by $1 \$$, the stock price of the banking sector will increase by 0.157992 assuming that the BI Rate and GDP variables are in conditions constant.

Based on Table 7 it can be seen that the exchange rate variable (US \$ to Rupiah) with a two-tailed test that uses a significant level of $\alpha=5 \%$, obtained a t-Statistic value of 0.943228 and a probability of $0.3596>0.05$. Thus Ho is accepted and Ha is rejected, meaning the exchange rate (US \$ to Rupiah) means that it has a partially insignificant effect on the stock prices of the banking sector. The positive regression coefficient shows that the greater the value of the foreign exchange rate is US $\$$, the higher the stock price of the banking sector on the IDX.

The results of this study are consistent with research conducted by Margareta Aryanto who found that the exchange rate had no significant effect on the stock prices of banking sector companies listed on the IDX. With this statement investors do not pay attention to the factors that influence the rupiah exchange rate. The high value of the rupiah that must be spent to buy US dollars, investors prefer to invest their funds in the country.

\subsubsection{Coefficient of GDP}

Gross Domestic Product (GDP) has a negative influence on the stock price of the banking sector with a regression coefficient of -5.96, which means that if GDP increases by 1\%, the stock price of the banking sector will decrease by 5.96 assuming that the exchange rate variable and the BI Rate are in constant condition.

Based on Table 7 it can be seen that the GDP variable with two-sided testing using a significant level of $\alpha=5 \%$, obtained $t$ Statistic value of -0.201299 and probability of $0.8430>0.05$. Thus Ho is accepted and Ha is rejected, meaning that GDP partially has insignificant effect on the stock prices of the banking sector. The negative regression coefficient shows that the greater the value of GDP, the lower the stock price of the banking sector on the IDX.

The results are in accordance with research conducted by Suramaya Suci Kewal (2012) which states that the Gross Domestic Product variable does not have a significant effect on the CSPI. An increase in GDP in a country indicates an increase in people's welfare in a country, so that it will encourage people to increase consumption of goods and services. The an increase in GDP indicates an increase in productivity that has an impact on increasing a country's income level, but this should not be considered domestic and foreign investors in investing capital must be in the form of stock investments.

\subsection{Coefficient of Determination}

From Table 7 above it can be seen the coefficient of determination (Adjusted R2) equal to 0.564040. With a coefficient of determination of 0.564040 , it can be interpreted that $56 \%$ of changes in stock prices in the banking sector can be explained by the three independent variables consisting of exchange rates, interest rates (BI Rate) and Gross Domestic Product (GDP). While the remaining $44 \%$ is influenced by other variables not included in the research model such as inflation, world gold prices and the company's fundamental factors, namely financial performance.

\subsection{Simultaneous Regression Test Results (Test F)}

From Table 7 above can F count equal to 9.194008 with probability (Fstatistic) amounted to 0.000904 . This shows that the probability $\varangle 0.05$ is $0.000904 \varangle 0.05$. This shows that the exchange rate, interest rate (BI Rate) and Gross Domestic Product (GDP) together have a significant effect on changes in the stock prices of the banking sector on the IDX.

\section{Conclusions and Recommendations}

\subsection{Conclusion}

- Interest Rate (BI Rate) has a significant negative effect on the price of company shares in the banking sector which consists of state-owned banks and state-owned banks listed on the Indonesia Stock Exchange (IDX). This means that the higher the interest rate (BI Rate), the lower the company's share price in the banking sector.

- The exchange rate does not have a significant effect on the company's share price in the banking sector, which consists of state-owned banks and state-owned banks listed on the Indonesia Stock Exchange (IDX). The results can be interpreted that the strengthening or weakening of the rupiah against the dollar has not been able to increase the price of company shares in the banking sector listed on the IDX. 
- Gross Domestic Product (GDP) has no significant effect on the company's share price in the banking sector consisting of state-owned banks and state-owned banks listed on the Indonesia Stock Exchange (IDX). This shows that increasing and decreasing gross domestic product can less influence investor interest to invest in the capital market.

\subsection{Suggestion}

- For investors, it is advisable for investors and prospective investors to always observe and follow developments in macroeconomic conditions because it will affect the right investment decision making.

- For further research is expected to develop research by adding other variables and prolong the coherent time.

- For academics and banking practitioners, the existence of this research can be used as one of the references or sources of references related to the capital market.

- In predicting stock prices, investors must also pay attention to other factors, namely direct or internal factors that can be seen from the company's financial statement data, other macroeconomic factors such as inflation, world gold prices, economic conditions.

\section{References}

i. Aryanto, Margareta. (2015). "Pengaruh Suku Bunga, Inflasi, Nilai Tukar dan PDB Terhadap Risiko Saham (Studi pada Sektor Perbankan di Indonesia yang Terdaftar di Bursa Efek Indonesia Periode 2011-2014)". Fakultas Ekonomi dan Bisnis, Universitas Dian Nuswantoro.

ii. Astuti, Rini, Joyce Lapian, dan Paulina Van Rate. (2016). "Pengaruh Faktor Makro Ekonomi Terhadap Indeks Harga Saham Gabungan (IHSG) di Bursa Efek Indonesia (BEI) Periode 2006-2015”. Jurnal Berkala Ilmiah Efisiensi. Volume 16, No 02, Tahun 2016.

iii. Assagaf, Aminullah, Etty Murwaningsari, Juniati Gunawan, and Sekar Mayangsari. (2019). "The Effect of Macro Economic Variables on Stock Return of Companies That Listed in Stock Exchange: Empirical Evidence from Indonesia". International Journal of Business and Management, Vol 14, No 8, July 2019.

iv. Djamaluddin, Said, Diny Rahmawati, Hapzi Ali. (2017). "The Influence of Fundamental Factors Micro and Macro to Return Expected Through The Intervening Corporate Value in The Listed Real Estate Sector in BEI Periode 2011-2014". International Journal of Business and Management Invention, Volume 6, Issue 2, February 2017.

v. Djamaluddin, Said, Rika Mirza Arisandy, Djumarno. (2018). "The Effect of The Fundamental Factors against Bank Stock Price Listed in Indonesia Stock Exchange Period 2013-2015". International Journal of Innovative Research \& Development. Vol 7, Issue 1, January 2018.

vi. Djamaluddin, Said, Muhammad Rizki, Apollo. (2018). “Analysis of The Influence of Macro Economic Factors against JCI Return in Indonesia Stock Exchange”. International Journal of Innovative Research \& Development, Vol 7, Issue 2, February 2018.

vii. Ginting, Maria Ratna Marisa, Topowijono, dan Sri Sulasmiyati. (2016). "Pengaruh Tingkat Suku Bunga, Nilai Tukar dan Inflasi Terhadap Harga Saham (Studi pada Sub Sektor Perbankan di Bursa Efek Indonesia Periode 2011-2015)”. Jurnal Administrasi Bisnis (JAB), Vol 35, No 2, Juni 2016.

viii. Jogiyanto. (2010). “Teori Portofolio dan Analisis Investasi, Edisi Ketujuh”. Yogyakarta: BPFE UGM

ix. Kasmir. (2014). Bank dan Lembaga Keuangan Lainnya Edisi Revisi. Jakarta: Rajawali Pers.

x. Kaur, Manpreet. (2016). "An Impact of Inflation and Exchange Rate on Stock Returns: Evidence from India". Scholarly Research Journal for Interdiciplinary Studies (SRJIS), Vol 4/ 37, 8232-8239.

xi. Kewal, Suramaya Suci. (2012). "Pengaruh Inflasi, Suku Bunga, Kurs dan Pertumbuhan PDB Terhadap Indeks Harga Saham Gabungan". Jurnal Economia, Vol 8, No 1, April 2012.

xii. Kitati, Edward, Evusa Zablon, dan Henry Maithya. (2015). "Effect of Macro-Economic Variables on Stock Market Prices for the Companies Quoted on the Nairobi Securities Exchange in Kenya". International Journal of Sciences : Basic and Applied Research (IJSBAR), Vol 21, No 2, Pp 235 - 263.

xiii. Laichena, Kaunyangi Eliud dan Tabitha Nasieku Obwogi. (2015). "Effects of Macroeconomic Variables on Stock Returns in the East African Community Stock Exchange Market”. International Journal of Education and Research, Vol 3, No 10, Oktober 2015.

xiv. Luthfiana, Hilmia. (2018). “Pengaruh Nilai Tukar, Tingkat Suku Bunga dan Inflasi Terhadap Indeks Harga Saham Sektor Properti yang Terdaftar di Bursa Efek Indonesia". Tesis. Program Studi Magister Manajemen, Program Pascasarjana Fakultas Ekonomi Universitas Islam Indonesia. Yogyakarta.

xv. Munib, Muhammad Fatih. (2016). "Pengaruh Kurs Rupiah, Inflasi dan BI Rate Terhadap Harga Saham Perusahaan Sektor Perbankan di Bursa Efek Indonesia”. Ejournal Administrasi Bisnis, 2016, 4(4): 947-959.

xvi. Saripudin dan Hilman Lutfi. (2017). "Pengaruh Makro Ekonomi Terhadap Harga Saham pada Perusahaan Sektor Perbankan di Bursa Efek Indonesia". Jurnal Bisnis dan Komunikasi Kalbisocio, Vol 2, № 4, Agustus 2017.

xvii. Septanti, Citra Putri, Hermanto Siregar, Hendro Sasongko. (2016). "Analysis the Impact of Macroeconomic on Financial Performance and Stock Returns of State-Owned Banks in Indonesia Stock Exchange 2000 - 2016". International Journal of Science and Research, Volume 5, Issue 12, December 2016.

xviii. Silim, Lusiana. (2013). "Pengaruh Variabel Ekonomi Makro Terhadap Indeks HargaSaham Gabungan Pada Bursa Efek Indonesia Periode 2002-2011". JurnalIlmiah Mahasiswa Universitas Surabaya Vol.2 No.2.

xix. Tandelilin, Eduardus. 2010. Portofolio dan Investasi Teori dan Aplikasi Edisi 1. Yogyakarta: Kanisius

xx. Wahyudi, Rifqi Nur, Muh. Asdar, Mursalim Nohong. (2017). "The Influence of Macroeconomic Variables Toward Jakarta Composite Index on Indonesia Stock Exchange".Jurnal Bisnis, Manajemen dan Informatika, Vol 14, No 2, Oktober 2017. 